\title{
Labor Market and Managerial Reform in the Albanian Civil Service, Improvements in the Status of Civil Servant under the Recommendations of the European Union
}

\author{
Prof. Alba Robert Dumi \\ Dean of Graduate School, "Ismail Qemali"Vlore University, Albania, \\ University of Tirana, Albania, Management Department, \\ Email:alba.besi12@gmail.com
}

PhD Ina Foto Barjamaj

PhD candidate, Institute for European Studies, University of Tirana, Albania,

Doi:10.5901/ajis.2014.v3n3p46

Email: ina.puravelli@yahoo.com

\begin{abstract}
The purpose of this paper is the study of employment and identification of gaps in the legal framework of the statute of Civil servants in Albania. This paper examines the question: Why labor market in Albania is left in neglect, why the Albanian public administration employees are not protected? Can a worker be protected by a legal framework away from the political change? This research paper will be focus on economic and legal aspects by comparing them. The paper tends to analyze theoretical and practical perspective modeling the best western Knowledge in human resources in general, since their reformation and consolidation will affect the growth of efficiency and effectiveness of public administration. As the Albania is a candidate that aims the membership in the European Union, the brunt of this integration process will be handle public administration. The purpose of this paper is to understand the administrative reform in the context of integration in the European Union as a link to a European space. How is being structured the Public Administration and which path should be followed for an effective reform. For this reason reformation of the relation of civil servants were given a special priority by the state. The study will focus on analyzing the current situation of civil service status, how it applies in the administration and how responsible are the institutions that are involved in the field of law enforcement for the well-functioning of the law "On the status of a civil servant." Aiming at improving the current situation and increase the scope of the law of civil service status also for other institutions.
\end{abstract}

Keywords: civil service, civil servants, recruitment, training, legal aspect, the Civil Service Commission

\section{Introduction}

The Albanian Government has undertaken a multifaceted reform, in this context the civil service reform has a primary role as the human resources, because they are not only one of the factors of the existence of any organization but they are also one of inspiration and "creators" of others factors, for reason the attention and investment in human resources should constitute the priority issues of reforming policies. Creating a stable civil service, motivated and above all professional and able to withstand the development and integration challenges of the country is at the center of the agenda of public administration reform. Reform is not just change the law. Reform is primarily a very different spirit.

This can be ensured through a recruitment based on professional intellectual merit, guaranteeing the rights, stability and motivation of civil servants and permanent and continuous improvement of human capacity. The civil service should be formed as an institution that requires its members a specific degree of professionalism and integrity, and good knowledge of administrative law and constitutional. The most important element of this reform in the public sector is the incentive related to the reformation of the public administration.

This process is necessary to face the challenges and to have better services with few sources possible.The public services are oriented by the input. The structures and the organizational procedures are created in order to involve the employees and need efforts and contribution from them. In the public service department the results are considered as a product of the efforts and staff's capacities. The requirement of these results is lead by an inspirational vision, which is a clear mission and has some strategic aims, and these aims are transformed in objectives which aim to improve the performance.

The market in Albania is full of low cost, high quality real estate for sale. There are literally thousands of brand new, great value apartments, houses and offices on sale now at unbelievable prices. Even in the best locations, such as the capital Tirana, or the coastal metropolis of Durrës there are fantastic bargains to take advantage of when it comes to 
buying Albanian real estate. From rural homesteads, to palatial urban apartments, there's property for sale in Albania to suit the needs of every potential investor, all at prices that can't be beaten - not even in neighbouring countries. Property in Albania is great value beyond belief!

Having long been overlooked by investors, Albanian properties are now beginning to be snapped up by savvy foreigners looking for a good deal. Albania is a rapidly developing economy, on the path to European integration, and as such is a safe bet for a healthy return on your investment. The state is responsible for a professional public administration, impartial and efficient that enforces the law. In this sense, a good civil service legally drafted and managed system enables the state to achieve adequate standards of continuity, and quality public services.

\subsection{Legal regulation of civil service status in Albania}

The Constitution of the Republic of Albania in Article 107 provides that "public officials enforce the law and are at the service of the people. Servants in public administration are been selected by competition. Guarantees of tenure and legal treatment of public employees are regulated by law." One of the 12 fundamental priorities, according to the European Commission's Opinion of 2010, Recommendation $6^{1}$, addresses public administration with an emphasis on civil service. It also highlighted the need to improve the civil service in law enforcement, reducing the politicization of public administration, the need for improvement in the area of wages, eliminating fragmentation of public administration, increase transparency, responsibility or accountability.

The signing of the Stabilization and Association Agreement ${ }^{2}$ is only the first step in the field of public administration reform in order to meet the standards of the Albanian public administration at the level of the European Union requirements. This necessarily requires professional civil servants, which guarantee the independence, integrity, transparency, the principle of service to the public, but also these civil servants deserve the respect of the rights provided for in the legislation field and if the latter were violated can be protected and restored by special organs of state. Today in our country there is a large number of laws and bylaws on the basis of which is set up and functions the Albania Civil Service. Existing legal framework took into account the experience of several European Union countries who have limited scope of the concept of civil service in the so-called "core public administration". Law no. 854911.11 1999, "civil servant status" is repealed by Law Nr.152 dated 01.10.2013 "On the Civil Servant", was published on June 7, 2013 in the Official Journal ${ }^{3}$.

\section{Literature Review and Hypotheses}

In many countries of Europe the public sector is going through a deep reformation. Improving performance, better services, and time spent on the assignments realization, the responsibility and the effectiveness of the programs and public services are very important to everybody, for the persons who offer these services and for the ones who receive it. But there are a lot of political, bureaucratic and technical hindrances that affect the performance of the Public Administration.

This law comes into force on 1 October 2013, its effects begins 6th months after entry into force. As at the date of commencement of the effects of this law apply the law 8549, dated 11.11.1999, "Civil Status". The law regulates the legal relationship between the state and civil servants and establishes rules for the administration of the civil service. The new law clearly defined scope and categories to be treated as a civil servant. The law regulates the relationship of the civil service by providing provisions for the rights and duties of employees, which is expanding the scope of rights and mentioned explicitly, the right to strike, the union membership and political.

It also regulates admission to the civil service categorization depending on positions that were made, in this way is regulated the lateral and promotion. Innovation of the new law with regard to institutions that create it provides relevant competencies are the creation of the School of Public Administration ${ }^{4}$ and Supervision Commissioner for Civil Service. An important provision of the new law is the transformation of the Civil Service Commission by a collegial body in an institution monocratic also reviewing its powers, passing the examination of complaints of civil servants from the Civil

\footnotetext{
1 Plani i Veprimit për Plotësimin e 12 Rekomandimeve të Opinionit të Komisionit Evropian për Shqipërinë gjendet në http://www.mie.gov.al/

${ }^{2}$ Ratifikuar me Ligjin Nr. 9590, datë 27.7.2006 "Për ratifikimin e 'Marrëveshjes së Stabilizim-Asocimit ndërmjet Republikës së Shqipërisë dhe Komuniteteve Evropiane e shteteve të tyre anëtare"

${ }^{3}$ Botuar në Fletoren Zyrtare nr. 95, datë 7.06.2013, faqet 3952-3976

${ }^{4}$ Shkolla shqiptare e Administratës Publike parashikohet vetëm në një nen të ligjit të ri për nëpunësin civil, në nenin 8, i Ligjit nr.152/2013
} 
Service Commission to the administrative courts 5 .

\subsection{EU-clauses in the reform of Public Administration.}

$\mathrm{H} 1$ Has the Albanian Public Administration undergone changes under the process of integration?

$\mathrm{H} 2$ Are protected on a legal and administrative framework the Albanian human resources, that can be effective in the future strength of Albanian integration in the framework of EU?

At the beginning of the ' 90 the role of the Albanian state was modernized, and was stimulated to economic improvement and to conceal social injustice. Small hydro is gaining ground across the Balkans. The small (municipal) Albanian investor is looking for medium-size hydro and dam companies who know how to tap special funds. (Quinn, R.E. Spreitzer, G.M)

This has been traditionally the arena of big players such as Siemens with specific staff to handle the World Bank, the European Investment Bank and the EBRD. The Balkans show small funding is happening. Brussels and USAID also have small technical funds in the agricultural sector which can mesh nicely with reservoir building for irrigation and domestic water projects. American banks are also very active in Albania. (Dumi A JERM 2012)

The performance evaluation is a process that makes the employees reflect, discuss and change their working methods. During the process the individuals can change their working methods and there may be changes even in their behavior. At the institutional level the process enables the systematic collection of data about the individual's performance.

\section{Methodology and Research Goal}

The extensive use of reservoirs for fish production as part of food security is expanding exponentially. There is a market for expertise on protecting big volumes of fish at the turbines, as well as fish ladders and other bypass schemes. (Quinn, R.E 1989)Reservoir stocks for the market attract EU funding and may be worth tens of millions of Euros. Food ministers want clean river basin waters reaching the sea which will not damage high value shellfish beds and fish breeding grounds.

The methodology used has passed the following phases:

1. the impact of the integration process in public administration

2. Analyse of the current legal framework, which has undergone changes and challenges facing.

3. Highlighted improvements in civil statutisin respective officers on the recommendation of the European Union

\subsection{Data and methodology of study in this paper research}

This article was made created by respecting all the methodological rules. The methodology of this article was based in two parts: Studying the foreign and Albanian literature, bibliographic studies, collecting data from official sources as MOE, ISKSH Albania, MOH, DHR Resources and from different publications such as magazines. And practicing, which is related with the interviews with leaders and employees of the Public Administration. To collect the data for this article we made interviews, questionnaires and other researches. We created also a questionnaire, which was composed by 130 questions and $5.8 \%$ of the employees in the central level of the public administration answered. We are concluding in these seven key factors for success, such as:

- A dynamic local government leadership

- A coherent strategy acted upon with determination

- A healthy climate of cooperation with business

- Local government's investment initiatives to jumpstart the stagnant economy

- Creative use EU funds to implement local policy

- Efficient municipal administration

No manager who is prone to both ulcers and accepting verbal statements at face value belongs at the labor relations bargaining table. Negotiations often begin with the union representatives presenting a long list of demands in both the economic and noneconomic (for example, administrative clause) areas. To naive management, many of these

${ }^{5}$ Neni 71, pika 3, e Ligjit nr.152/2013, datë 30.05.2013 
avowed labor goals seem at best unjustified, and at worst to show a complete union disregard for the continued solvency of the employer. Although extreme demands, such as a new golf course and free transportation in company cars to and from work for all employees, are rarely taken seriously, the management negotiators may be asked for economic that are well beyond those granted by competitors and noneconomic ones that exhibit a greater use of vivid imagination Staw, B.M \& Ross, J. Journal of Applied Psychology, 1980, 65(3), 249-260.

An overview of the status quo in the countries of Western Europe provides an overview of solutions, different models, to facilitate the achievement of these objectives. In some EU member's states, most state employees have civil servant status. This means that they are governed by a civil service law and its secondary legislation, and not by the total labor laws establishing minimum standards for contractual relations between employees and employers in the private sector. This happens in Belgium, France, Greece, Ireland, Netherlands, Portugal and Spain. In other states, only a part of the permanent government employees have civil servant status. Those who are not civil servants are regarded as simply a profession in the public sector of the economy, or within the public services financed from the state budget.

\subsection{The role of the Albanian School of Public Administration in the creation of a stable civil service and professional}

The Albanian School of Public Administration ${ }^{6}$ has replaced the Public Training Institute and has the same powers. In collaboration with institutions of central and local public administration will be conducted trainings for civil servants. ASPA Currently is projected to be under the Ministry of Interior, but has administrative autonomy and autonomy in determining the curriculum of training programs and training. It aims the professional training of public administration officials. According to the Council of Ministers for ASPA-n bodies are:

a. director;

b. consultative board, which is an advisory organ of the ASPA and consists of general secretaries of all ministries, the director of the Department of Public Administration, two representatives from local government associations and two representatives of the University of Tirana, appointed by the rector of this university, with ASPA's request. Ministries and other institutions of public administration set up in June of each year, the need for training for their employees during the coming year, which shall submit to action ASPA's ${ }^{7}$. Director of ASPA's categorized as a civil servant.

Tab 1: Long term characterized and short term perspectives.
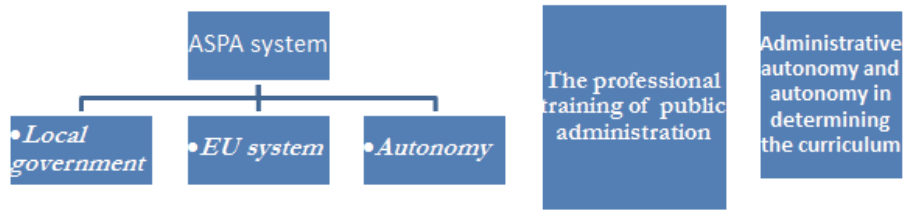

Source: Dumi A, MJSS, Nr 32012

An important provision of this decision is forecast to employee involvement transitional TIPA in ASPA's organization chart for 2013, without making substantial changes except change in the designation of job positions, where the term 'Training Institute of public Administration 'is replaced with that of' Albanian School of public Administration. ${ }^{8}$

Law is enriched in terms of predictions ASPA programs that offer. Thus, ASPA has a duty to provide professional training through the inclusion of the following programs:

a. thorough training program,

b. continuous training program,

\footnotetext{
${ }^{6}$ Vendim i Këshillit të Ministrave nr.220, datë 13.02.2013, Fletorja Zyrtare Nr.54, "Për krijimin dhe funksionimin e Shkollës Shqiptare të Administratës Publike dhe trajnimin e nëpunësve të administrates publike"

7 Pika 6 e Vendimt të Këshillit të Ministrave nr.220, datë 13.02.2013, Fletorja Zyrtare Nr.54, "Për krijimin dhe funksionimin e Shkollës Shqiptare të Administratës Publike dhe trajnimin e nëpunësve të administrates publike"

8 Vendim nr.461, datë 30.05.2013, "Për disa ndryshime dhe shtesa në Vendimin nr.545, datë 11.08.2011 të Këshillit të Ministrave "Për miratimin e strukturës dhe nivelit të pagave të nëpunësve civilë, nëpunësve, zëvendësministrit dhe nëpunësve të kabineteve në Kryeministri, aparatet e ministrive të linjës, administratën e Presidentit, Kuvendit, Komisionit Qendror të Zgjedhjeve, Prokurorinë e Përgjithshme, disa institucione të

pavarura, institucionet në varësi të Kryeministrit, institucionet në varësi të ministrave të linjës dhe administratën e prefektit"
} 
Also, ASPA offers the possibility of preliminary preparation of candidates to take part in the open competition for executive category, and carries towards the tariff studies and publications in the field of public administration. ASPA's students, selected from civil society, business, or individuals outside the civil service are obliged to pay the fee.

\section{Improvements in the Status of the Civil Servant According to the Recommendation of the European Union}

We live in a time when Albania is making efforts to obtain candidate status for membership in the European Union. EU membership requires respecting the acquis communautaire. To do this effectively public administration should apply the general principles of good governance and to meet administrative standards set by the European Union ${ }^{9}$. The implementation of the acquis in the administrative direction is a matter of resources and capacity within the relevant sector and not only. The overall system of governance in a horizontal candidate must meet the requirements of the European Union since these depend on the functioning of the administration. Successful implementation depends entirely on governance structures and system that is built for this purpose, as are the procedures for administrative actions and mechanisms that guarantee performance of civil servants in accordance with EU standards. ${ }^{10}$

Public administration reform has been for the past two years among 12 priorities set by the European Union. Formally, this condition is fulfilled by the new law on civil service. We say nominally, because law, must first enter into force, the second should be monitored and analyzed implementation and its effectiveness in practice in order to reach a certain conclusion regarding the Albanian public administration reform as meets professional civil service, sustainable, politically neutral, based on merit and job seekers are drawn to Albania because of the motivational elements of labor relations in this service.

In Tirana sustained population growth since 1991-1999 led to rapid expansion of the urbanized area, resulting $n$ the proliferation of informal settlements. With an estimated population of 575.000 in 1997, 6.500 families were seeking new housing each year. Local government, even with central transfers, could accommodate only five percent of the demand for new infrastructure.

Supported by donor assistance and international and local NGO's the city initiated a community-based development strategy in the informal settlement .The program brought together local government teams, NGO's and residents to formulate a development plan for the neighborhood define priorities for improvements and determine equitable cost-sharing formulas to finance infrastructure. In 1992- 1999, the city's Urban Planning unit decided to initiate participatory process to rehabilitate and revitalize the districts. The process required an extensive outreach effort, involving consultations with every household.

Tab 2: Long term characterized and short term perspectives.

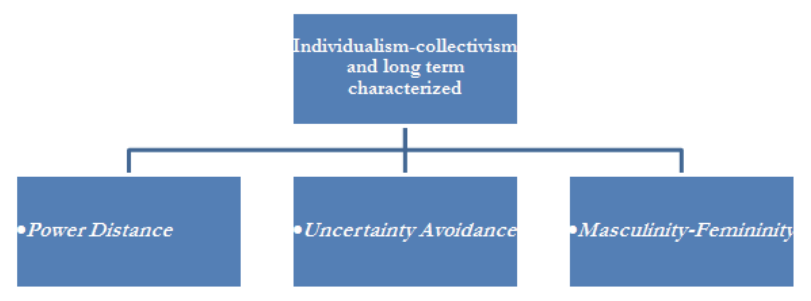

Source: Dumi A, MJSS, Nr 32012

- The performance evaluation conditions the emplacement and the implementation of the standards as referential points. Emplacing standards would increase the responsibility for each post in the Public Administration and will help in monitoring the performance of the institution. Lack of access to land and the on going process of fragmentation of family holdings have led to widespread poverty, prompting out migration.To meet these daunting challenges, the canton democratized its planning and management procedures. This

\footnotetext{
9 Për më shumë informacion shihni Meyer-Sahling, J. (2009), "Sustainability of Civil Service Reforms in Central and Eastern Europe Five Years After EU Accession", Sigma Papers, No.44, OECD publishing, gjendet në http://dx.doi.org/10.1787/5km/60pvjmbq-en

10 OECD (1999), "European Principles for Public Administration", Sigma Papers, No.27, OECD Publishing, faqe 6, gjendet në http://dx.doi.org/10.1787/5km/60zwdr7h-en
} 
process allowed the canton to build consensus, prepare a development plan, allocate municipal funds equitably leverage additional resources and improve infrastructure and living conditions. The participatory municipal management improve infrastructure and living conditions. The participatory municipal management process was institutionalizes ensuring representation of women and marginalizes groups.

The new law on civil service is expected to be adopted and enter into force, among which the most important provisions are:

a. Expanding the scope of the Civil Service Law,

b. The group recruitment closely related to the improvement of current methods of testing,

c. Creating the Troop of Senior Leaders in Civil Service

d. mobility,

e. exchange,

f. Transfer and replacement.

The new law aims to correct the flaws that have emerged in practice over 12 years implementation of Law No. 8549, dated 11.11.1999, "civil servant status." Thus, in terms of recruitment, the new law by organizing competitions for recruitment and retention of group recruitment results for two years aims to shorten the time of the recruitment of civil service position vacant - a competition, lower costs for the entire process from the publication in newspapers, given that throughout the recruitment process could also appeal, something that automatically interrupt continuity of the process. Also, the new law strengthens and increases expectations powers to implement the recommendations of the Commissioner of Civil Service Supervisors recognizing the right, as an administrative body, to impose fines to correct cases of lawlessness during the administration of the civil service in all institutions included in the scope of application of the new law.

\section{We Recommended these Conclusions}

This law brings several important innovations in the field of Public Administration:

First, it strengthens the unity and homogeneity of the regime of employment in civil service, includes in the regime of civil servants addiction institutions who were not seen, as well as local governments, bringing the number of administration employees who have civil servant status, from 6 thousand to about 20 thousand, starting from April 2014.

- It is necessary to plan and develop training for better recognition of existing law by civil servants, especially the human resources staff, should be taken into consideration changes in the law on local governments in order to achieve the connection between the new law and civil service organization and functioning of local

- government institutions.

- to try and manuals developed methodology for measuring the performance of the institution.

- The capacity of the civil service management institutions like the Department of Public Administration and Oversight Commissioner of the Civil Service should be strengthened.

1. Introducing participatory planning and community-based development processes through neighborhood development committees and street representatives working in partnership with the city

2. Creating an enabling environment for private investment

3. Empowering citizens to pursue their own self improvement

4. promoting privatization of the housing a stock and fostering the development of micro- enterprises

5. Ensuring the sustainability of activities initiated

6. Promoting the reliability of successful initiatives.

Albanian government will be reality these points:

- A dynamic local government leadership

- A coherent strategy acted upon with determination

- A healthy climate of cooperation with business

- Local government's investment initiatives to jumpstart the stagnant economy

- Creative use EU funds to implement local policy

- Efficient municipal administration 


\section{References}

Staw, B.M \& Ross, J. Journal of Applied Psychology, 1980, 65(3), 249-260.

Stogdill, R.M. personal factors associated with leadership: A survey of the literature. Journal of psychology, 1948/, 25, 35-71.

Van Fleet, D.D \& Yukl, G.A. military leadership: an organizational behavior perspective. Greenwich, CT: JAI Press, 1986.

Vroom, V.H \& Yetton, E.W. Leadership and decision making. Pittsburgh University Press, 1973.

Wheaton, B. Assesment of fit in overidentified models with latent variables. In J.s. Long (ed), Common problems/propers solutions: Avoiding error in quantitative research. Beverly Hills, CA: Sage, 1988.

Yukl, G.A. A New Taxonomy for Intergrating Diverse Perspectives On Managerial Behavior. Paper presented at the American Psychological Association meeting, New York, 1987.

Yukl, G.A. leadership in organization. Englewood Cliffs, NJ: Prentice-Hall, 1989. (a)

Zaccaro, S.J, Foti, R.J \& Kenny, D.A. Self-monitoring and trait-based variance in leadership: An investigation of leader flexibility across multiple team situations. Journal of Applied Psychology, 1991, 76(2), 308-315. 